\title{
The Role Indigenous Institutions in Resolving Land Related Conflicts: A Case Study of Two Kebeles ${ }^{1}$ in Fogera Woreda ${ }^{2}$, North-West Ethiopia
}

\author{
Dr. Balew Baye Assefa \\ Assistant Professor in the department of History and Heritage Management \\ Administration Vice President, Debre Tabor University
}

\begin{abstract}
This study sought to study the role of traditional conflict resolution in the context of mediation council among two kebeles of Fogera District. The study also attempted to explore the procedures mediators used during the resolutions. In order to realize these objectives, the study employed qualitatively designed research methods. Observation and case study were employed to generate data used for the analysis. The findings of the study showed that the traditional council of conflict resolutions has played a vital role in dispute resolution. Members of the mediation council exerted their effort to control the course of the mediations which had direct impact on the final decision to be made. Indeed, the cases showed that the council members mostly advocated win-win approach to the problem sustainably. The study, therefore, suggests some areas of research to be undertaken in the future.

Keywords: Conflict, Claimant, Defendant, Resolution, Mediation and Mediator.
\end{abstract}

DOI: $10.7176 /$ IAGS/83-01

Publication date:June $30^{\text {th }} 2020$

\section{Background of the study}

Conflicts are worldwide phenomena and they are becoming part of the socio-political life in Ethiopia. Several studies show that during the past four decades, rural societies in Ethiopia have experienced inter and intra-ethnic, state-society and inter-state conflicts (Befekadu and Diribassa, 2005; Markaris, 1972 and 1994). Moreover, internally rural community conflicts in Ethiopia are reported to have increased in their frequency, intensity, duration and magnitude of damages they inflict among the conflicting communities. This increase in ruler conflicts was attributed to lack of social development, bad governance, inappropriate policies, drought, population increase, land and resources scarcity, food insecurity and rural poverty. In most instances, it is reported that the principal victims of such local conflicts were and are rural women, elderly, children, and the disabled.

An illustrative example for this kind of conflict is the conflict in Fogera Woreda. In Fogera conflict over land is one of the most important sources of conflict. Conflicts overland have different forms. They vary from disputes caused by border violation, transfer firths, sale, exchange and dispute rooted in the land policy of the region. These sorts of conflicts are one of the social problems in the woreda, as it is the case in many parts of the country (Yohaness, 1998). Though, the conflicts are severe social problems, they have not been studied and they deserve due attention in this regard. In fact, resource based conflicts in Fogera and its surrounding have increased over the past years (Ibid). These small-scale community level conflicts have undermined the economic, social food and environmental security of the rural agrarian communities in Fogera and other districts of the region. These rural conflicts undermined the regimes (the regional /federal governments) rural community/ agrarian centered economic development and poverty reduction efforts which aimed at ensuring long-term political stability, socio economic development, and food security among rural societies in the area.

However, unlike political conflicts between state and society or inter state and regional conflicts, rural smallscale land related conflicts have not attracted attentions of policy makers and researchers. This calls for timely research work on these local level conflicts by Ethiopian scholars and academicians to generate research based facts that will help policy-makers design and implement context and evidence based policy interventions for their peaceful transformation. From this point of view, this study focused on to assess the role of traditional council of conflict resolution in resolving various land related conflicts in the study area.

\section{Theoretical Approach}

Conflict is a universal factual phenomenon occurring in any society at any level. Conflict exists in any society at part of the world though its magnitude and frequency varies from situation to situation and from place to place (Yigremew, 2004). The prevalent conflicts, then, require sound resolution mechanisms (Ibid). Africa having one of the highest records of conflict has developed its own traditional conflict resolution institution that base fits to the way of life of its societies. It can be said that main objective of conflict resolution is to materialize peaceful solution of the conflict, no matter how systems of conflict management differ from society to society to society

\footnotetext{
${ }^{1}$ The lowest unit of administration in Ethiopian government structure.

${ }^{2}$ Refers to a district in a certain region.
} 
(Wiliam, 2000). Conflict resolution methods can be grouped into two: coercive and none coercive methods. The difference between the two lies on the approach to conflict resolution, which in its turn impacts the outcome. Coercive conflict resolution method is a mechanism in which the conflicting parties play little role or no role in choosing the forum. In this method the decision passed are binding to all parties (ibid). This method is mainly manifested in judicial systems and also arbitration. Non-coercive method, however, is a situation in which the conflicting parties enjoy a great deal of autonomy in choosing the form. Mediation and negotiation are examples of the method (Mwagiru, 1999).

African traditional conflict resolution mechanisms fall in the second category; which is non-coercive. This is what differentiates traditional council of conflict resolution from those western systems of conflict resolution. Traditional council of conflict resolutions are known to be integrative. In these mechanisms the focus is on paying attention to the interest of all conflicting parties to be reconciled as far as possible. Even if a member involves in a conflict against its own society, the focus would be on ways of integration of that member back into its society. This often results in integration, and restoration of peace among the society (William, 2000).

Furthermore, in traditional council of conflict resolution, the society is responsible for the offence of its member on its own society. It is assumed that the society have taken preventive measures to do away with that conflict. Thus, as the society shares the blame with the errant, they would take shared responsibility to resolve the (ibid). Traditional council of conflict resolution emphasize on keeping social order. As the primary focus of traditional council of conflict resolution is reconciliation and reintegration, it brings about long lasting solution. However, unfortunately, traditional conflict resolution methods are loosing their autonomy due to the impact of system of conflict settlement the of course emphasizes the rule of law. The settlements often bring about sort-lived outcomes (Mwagiru, 1999; Mohiddin, 1999).

As the African traditional conflict resolution method is a win-win method, all the voices of contestants are heard on equal basis, they tend to respect the interest of all parties, as the result of which they work fairly well and if they are to be refurbished, they will play pivotal role to preserve the unity of a society (Mwagiru, and Mohiddin, 1999) pointed out that Africa is a hub of numerous ethnic groups, cultures, and societies speaking different languages. Thus, it is also a home of various methods of conflict resolution each cultural group having its own variant method within the umbrella of traditional approach of conflict resolution.

In relation to land conflict, this study investigated how the conflict resolution mechanism within the framework of African method of conflict resolution play role in conflict resolution in the case of Fogera community.

\section{Research Methods and Materials Research Paradigm}

This study is based on the philosophical foundation of the Constructivist Research Paradigm. To begin with, the epistemological views of constructivism disregarded "the existence of an external objective reality independent of an individual from whom knowledge may be collected or gained (Given, 2008:116). For scholars advocating the importance of constructivist paradigm, reality is socially constructed. It means that subjects can construct knowledge through social interactions in the world (Creswell, 2009). Constructivism emphasizes a shift from explaining phenomena, which is very distinctive in the natural sciences, to focusing on understanding phenomena in the human sciences (Given, 2008). Thus, for constructivist paradigm, humans should be studied within the context of their social and cultural lives, not with a mechanistic explanation (Ibid.). Therefore, the constructivist paradigm is very important to better understand environment, social institutions, language, culture, belief systems and so on and consequently to construct meanings humans ascribe to their experience in the social world" (Given, 2008:116). It is assumed that individuals could connect the reality in the social world to their prior knowledge to construct meanings. In light of this, the constructivists' assumptions are deemed suited to this study.

\section{Research Design}

The study used a qualitative research approach of data collection and analysis. Qualitative approach often deploys individual methods of assessment of opinion, attitude and behavior. According to Victor (2006:249), "qualitative research uses a range of methods to focus on, the meanings and interpretation of social phenomena and social processes in the particular contexts in which they occur". Creswell (2009) also writes that qualitative research is devised to deal with social phenomena and human behavior in the natural settings. Therefore, by considering the above characteristics, the qualitative approach is found to be a key research approach to this study. In light of this, in order to collect detailed and natural data for the study, three dispute cases were identified among the $27 \mathrm{k}$ ' ebeles of the study area. Two cases were chosen for the study. In so doing, they are labeled as "Case-1" and "Case-2".

\section{Sampling}

Since the main aim of the study was to deal with representatives of traditional council of conflict resolutions in the study area, a non-probability (or purposive) sampling method was used to get adequate and relevant data. In fact, the adoption of the non-probability sampling is important for the fact that it was impossible to record the traditional 
council of conflict resolutions council of elders' cases and participants in all kebeles of the district.

\section{Research Site Selection}

Essentially, two significant rationales made Fogera district to be selected as the study area. Primarily, the district is known for the prevalent land-related conflicts in the region (MoA, 2012). The cause for the widespread existence of the conflict is the pervasive production of crops, particularly rice. Rice is becoming very important crop for the farmers. Conflict is often imminent, whenever farmers needed sizeable land to produce the crop. Besides, the communities in the district depend largely on traditional council of conflict resolutions to resolve the widespread conflict that occurs among them. The present researcher's prior knowledge of the scenario made the district to be selected as the research site. Although, countless land-related conflicts occur in the various kebeles of the woreda, only three kebeles were purposely selected from the outset.

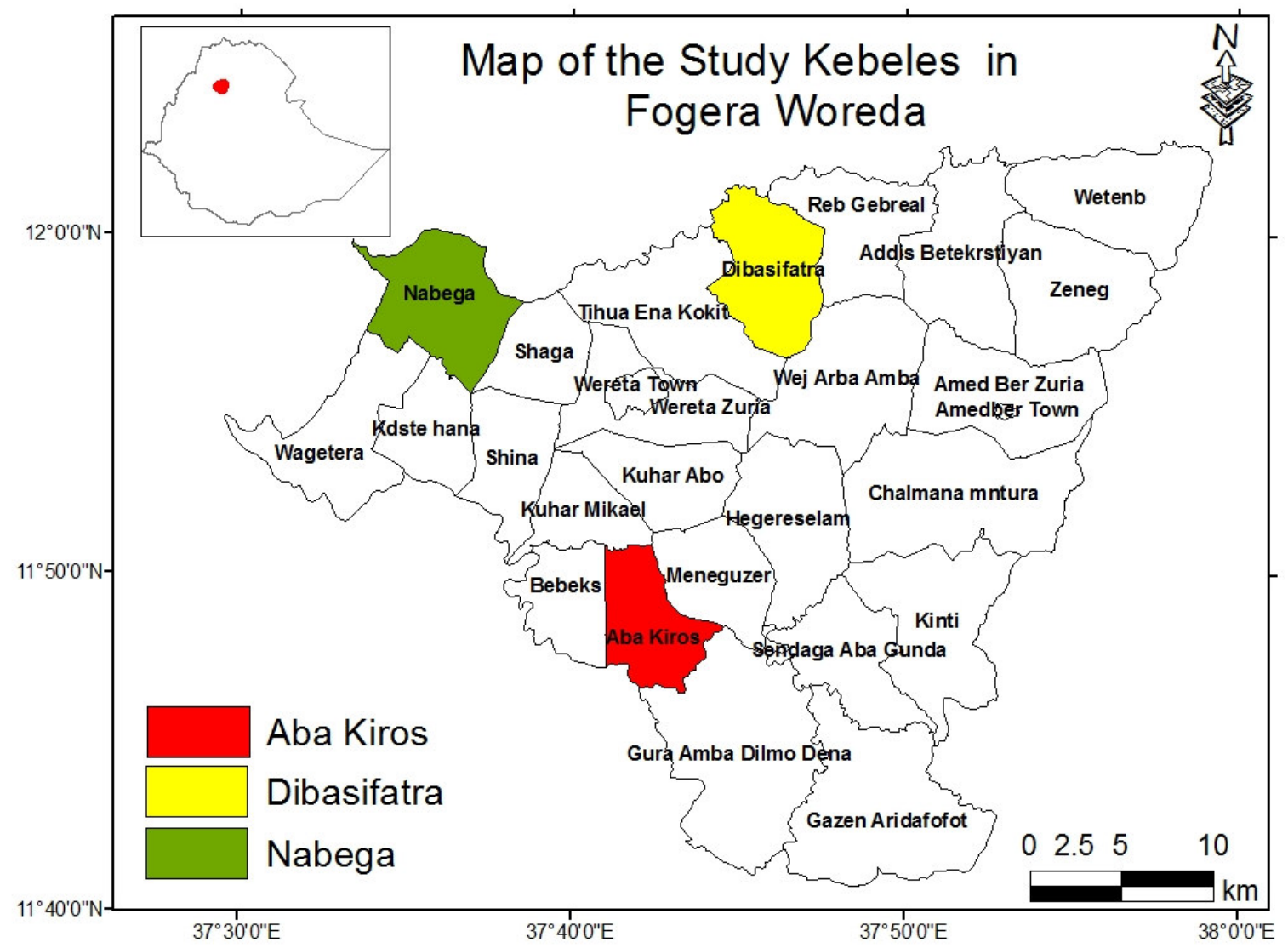

Figure 1:Map of the study $\boldsymbol{k}$ 'ebeles in Fogera District (Adapted from: Google Earth.Com)

\section{Selection of Cases}

The fundamental rationale for the selection of those cases was the specific types of land-related disputes that happened recurrently in the study area. Of course, the selection was made to get data that would be useful to identify specific case scenario of the causes of the dispute, the parties involved in a dispute and the resolution proceedings. As different types of land-related deputes are happening in the selected kebeles, the identification of those dispute cases based on the similarity of their causes is very important to unearth conflicts and their resolutions through the traditional council of conflict resolutions.

\section{Selection of Participants}

The subjects of the study were local councils and disputants who gathered to resolve conflicts in the villages of the research site. The council comprised local farmers who were usually selected by disputants and sometimes by members of the council. All the available members of the council who participated during the mediation were recorded, though individual members differ in the amount of time they talked and their rhetoric ability because of their age, experience, knowledge and socio-economic status.

\section{Data Collection Methods}

In this study, primary data were collected in the actual presence of the researcher who observed the council of elders' proceedings and facilitated the recording of the events in their natural settings. The method helps to 
generate valid linguistic and ethnographic data to be used in the study under investigation (Crystal, 2010). Thus, the following primary data collection techniques were employed for this purpose.

\section{Recording of Dispute Resolution}

Video recording was one of the most pertinent primary data collection techniques employed in this study. It was obvious that this kind of study required the recording of each activity of the resolution procedures and discourses. The role of video recording was very indispensable to capture real interactional situations. Besides, video recording was very essential to generate ethnographic data of the mediation proceedings that were utilized as the main source of primary data Bloor and Wood (2006).

\section{Observation}

It is believed that in field data collection, especially in issues like the council of elders discourse, observing interaction is essentially useful. It is essential to observe and consequently to comprehend the pros and cons of the resolution procedures and the discourse of interaction (Spradley, 1980). Observation enabled the researcher to get firsthand account about the tradition of the communities which is important in the analysis of the discourses the resolutions.

\section{Methods of Data Analysis}

In this study, case analysis method was used to analyze how the traditional council resolved land related conflicts. Data transcription, translation and annotation have been done before the analysis was done. The analysis is based entirely on these cases identified to incorporate representative discourse of the traditional councils. Each gathering holds slightly different themes and stories, which provided the process of resolution in somehow diverse settings. The cases also highlighted the panorama of causes of conflict and resolution processes. They were used to analyze and document the council of elders procedures and the discourses unfolded thereof.

\section{Finding and Case Analysis}

\section{Overview of Traditional institutions of conflict resolution}

Thought the participation of the society is necessary indigenous conflict resolution mechanisms, the role of the community elders is the main component of the council. Traditionally, elders play positive role in the process and bring about long lasting solution. Most time, elders and wise men among a family can be elected as a member of the council. They enjoy great deal of credibility and their decisions are taken as objective. In order for a person to be recognized as a council member, he should practice engagement in public affairs. He has to know about culture, norms, values and history of the society as well as equips himself with the necessary skills of negotiation and persuasion. Moreover, he gets the acceptance of the society before he assumes the role of reconciling people who are in conflict.

Moreover, in order to be a community elder, one has to be articulate enough. One is accepted as an elder only when he proved that his speeches are persuasive enough to bring people to reconciliation. To be a mediator requires presentation of the norms values and traditions of the society. As people who are in conflict tend to be emotional, an elder has to skillfully calm them down by avoiding assumption that would worsen the conflict. He has to be able to explain the importance of making peace and has to convince them. This explains the reason why Amhara people, in general and Fogera society, in particular, tend to give different responsibilities for individuals proved to be able orators. They say someone should be elected if he is skillful orator. This all show the emphasis the society gives for people with wisdom of speech. In general, being an orator is an important qualification for being elder of the community.

Another quality that is expected of an elder of the community is that he should be neutral and should have balanced view. He has to do away with discrimination of any sort. In conflicts within a family or the community at large; he has to treat both parties on equal terms. Even if one of the participants of the conflict is his closest kin, the elder is supposed to be neutral. The elder himself discloses his neutrality by swearing in the name of God often in the process of reconciliation to escape being suspected as having bias. The neutrality of council is one of the factors that contributed to its success and acceptance by the community. It does not also open the way for corruption. The balanced view of the elders gave them acceptance and respect by the disputants. The decision of the elders does not consider whether somebody is rich or poor, man or woman and so forth. The main objective of the reconciliation is making peace. They rather take care not to put women and children at disadvantage. In addition, if the disputant is a young individual against old one, the old one would be given priority to make his/her point first. This all adds to the respect of the deeds of the council.

\section{Process of Mediation}

The objective of traditional conflict resolution is to impartially help disputants resolve their dispute in a peaceful manner. However, though the council of elders can oppose the claim of one or both disputants, it has no power to 
impose a binding decision on the disputants. In the course of mediation the elders can take different approaches. Some might take processes and decisions that are mainly interest based. In this case their decisions take the interest of both parties in to consideration and look for a win - win solution. Most often these conflicts are solved by sharing the disputed plot of land for both parties on equal terms.

On the other hand, some community elders use rights based approach to conflict resolution. In this regard the council traces the legitimate rights of a given plot of land. If two individuals claim the same plot of land they strive to establish who possessed that land in the past and who the legitimate owner should be. They consider both the pre 1974 land tenure system and the 1997 land redistribution ${ }^{1}$. In this way the council would be in a position to distinguish the legitimate of that plot and pass decision that ensures his/her right.

\section{Case-1: Conflict instigated by border violation}

In the rural parts of Fogera, land is very much fragmented and an individual shares different boundaries with lots of individuals owning piece of land round him. Though peasants respect their boundaries, under normal circumstances, sometimes encroaching one's boundary in an effort to make the size of their plot bigger is common. The researcher obtained information about the council that was convened to resolve the conflict caused by border violation. With the permission of relevant elders he was able to observe the process.

Both the plaintiff and the defendant are residents of the same kebele whom the shared a boundary, as their plots are side by side. The plaintiff noticed that the defendant had continuously trespassed the boundary between them. As it is customary in the society, the plaintiff raised the issue to the defendant on their plots of land. However, the defendant refused that he has farming his own land by respecting the boundary. Then plaintiff brought the matter to the attention of the council.

The council discussed the matter in detail after which it decided to see the boundary before making their decision. The case was adjourned to May 27 2019, which is a day dedicated to Holy Savior on which day there is no work. On that day all members of the council as well as the disputants visited the boundary between the two. Then they sat for further discussion and invited the disputants to speak once again if they have anything to say.

Then the elders discussed the matter and reached an agreement that both sides should live a $50 \mathrm{~cm}$, land as a boundary. They called the disputants and disclosed the final agreement they reached. However, the plaintiff claimed that it is unfair and he will not accept it. On the other hand, the defendant explained his decision to accept the agreement the council. They blessed him and continued to persuade the plaintiff to do the same. After much effort they managed to convince him too. He said "the decision is not fair, but I cannot refuse your decision thus I accept the terms of the agreement." The council members were happy with the success of their effort. They blessed him too. Then, a formal written agreement was prepared in three copies. The disputants took one copy of the agreement for each of them. The third copy was given to the head of the council. This was the conclusion of the reconciliation process.

\section{Case-2: Land Dispute due to inheritance Prelude}

During the 1997 land redistribution the disputants were under aged and this did not allow them to acquire land on their own. As their father was an official of the woreda administration during the $\mathrm{Derg}^{2}$, he received only four qedem ${ }^{3} a$. The two were dependent on their family. Their father died in 2002 and they continued to live with their mother. However, in 2005 their mother married another person and moved to a small town nearby. Following this the eldest of the two brothers decided to marry a wife and lead his own life. Then he asked his brother to share their parent's land.

His brother had a different position. He insisted that as the land is very small it is useless to share. Rather he proposed that they should work together on their land and should not marry till they get enough land. The elder brother was not in a position to accept this deal and the two brothers clashed. They started to intimidate one another. The elders were gathered to settle the problem by claiming that they will not sit and see the brother kill one another. The researcher had previously arranged an interview with the head of the council who told him that he is going to mediate the brothers.

At the gathering of the council the first to make speech was the head of the mediation council, who is an elderly relative for the disputants. He stressed that they gathered by the will of God and to do what God valued most. He explained what God likes peace and love. If love and peace is missing between brothers everything is useless. So, he encouraged them to speak frankly, what the real source of their problem is. The elder brother was given a chance to present his case first as per the tradition of the society. The council members heard both parties' claims and counter-claims. They held detailed discussion of the issue. Then they called the disputants to come closer, and urged both to be calm and listen to the decision. They explained that their decision is free of partiality

\footnotetext{
${ }^{1}$ After 1974, the great Ethiopian Revolution, the then government distributed lands to poor farmers all over the country.

${ }^{2}$ Means, committee in Geez language.

${ }^{3}$ One qedema is equivalent to one hectare of land
} 
and the main intension is to enable them to live together peacefully.

Decision: The council members stressed that making peace is rewarding both in this earthly life and in front of God. After they heard the disputants points of views, the council decided that the elder brother should take the two qedama land and look for a another house to live.. As far as younger brother is concerned, he must take the remaining two qedama land. In addition he will take the residence of his family. Thus, your family's asset will not be destroyed.

After listing to the decision of the council, both disputants stayed quite. The council members encouraged them to say something that shows their acceptance of the agreement. The disputants showed their agreement after which they were asked to greet each other. The head of the council blessed both of them that was a signal for the conclusion of the resolution process.

\section{The role of youngsters in Conflicts and conflict resolution}

According to the understanding of Fogera community, young people are those sections of the population that are matured for marriage and individuals to the average of twenties years of age. This category of the society knows the economic importance of land they given special attention to land. They will do whatever is possible, to ensure that they gain ownership over certain plot of land. As land is scarce resource in the society, there is a large proportion of this age group who are landless or who do not have enough land.

It is said that most of the young members of the society are source of conflict. In fact, many young individuals take part in a conflict, one way or another. In some instances, they are identified to be the causes of conflict in the district. It is also evident that rather than looking for ways of peaceful resolution, sometimes, they have a tendency to use force to do away with their rivals. It is also difficult to persuade them and put an end to conflict during the course of mediation process.

\section{The role of women in conflict resolution}

In Fogera, as it is the case with the Amhara Society at large, women have specific roles assigned to them by the society. Regardless of their marital status, women have to limit themselves to house activities. In the house women acquire great responsibility and assume important roles. Raising children is responsibility of women. Thus they have a great role of shaping the next generation. Managing of the house is also a responsibility left to women. Though the role women play have recognition among members of the family, women and men do not enjoy the same recognition among the society. Women are victims of harassment and violence. In Fogera Woreda it is becoming common that women leave their home without their share of property, when they divorce. So, women often take their case to the court rather than to the traditional council of conflict resolution. This has been making conflict in the study area widespread and protracted.

\section{Emerging Trends in traditional council of conflict resolution}

It is already discussed that traditional council of conflict resolutions have evolved and persisted to the present time by adapting to or resisting the challenges it has been facing. However, the introduction of the kebele administration at the local level as the government institution and the expansion of various modern infrastructures have negatively influenced the traditional council of conflict resolutions and the outlook of the people at large. The challenge from the state emanates from the way it viewed the traditional council of conflict resolutions s as inferior to modern institutions. In fact, the former bear better outcomes in small-scale dispute resolution. On the other hand, in modern courts dispute cases at all levels tend to be largely channeled through very complicated modern government set-ups and there seems to be an over emphasizes on the role of the law as the primary agent of conflict resolution through cases brought to modern court are usually getting protracted, and sometimes result in an unjust decisions.

The challenge has still persisted to the present and the state has become a potential threat to traditional council of conflict resolutions. Its approach in such manner may not be a deliberate action. It is very widely known that the government's policy is to enhance good governance through decentralization of power. In fact the threat is spearheaded by the ferd shengo, which is given the legal status to function as a judicial body of the kebele. The ferd shengo is the most controversial organ of the kebele but expected to manage and provide remedies for any social crisis at the local kebele level. Despite the fact that huge numbers of cases were brought to and instead of giving a due response the ferd shengo postponed almost all the cases to two and three years. Due to the action of the ferd shengo disputes have become protracted that reconciliation ultimately unmanageable.

The ferd shengo regards the traditional council of conflict resolutions as less functional, which has no legal base to manage conflicts, especially, disputes related to land uses. As many of the local officials said, "The ferd shengo is the only legal institution endorsed by the state proclamation to deal with land dispute cases."

These days, every Tuesdays and Thursdays crowd of peoples appealing to the ferd shengo nevertheless almost all the cases returned without even being registered. Some of the disputants who brought cases to the ferd shengo in the kebele were those who first brought their cases in traditional council of conflict resolutions. However, 
knowing that ferd shengo is politically recognized and legally supported institution than traditional council of conflict resolutions, they violate the consent they reached at the council of traditional council of conflict resolutions. Despite the fact that there was also a gedo ${ }^{l}$ in the agreement signed by the disputants and the council, the disputants sometimes reject the accord and went to appeal to the ferd shengo. Because they know that no governmental body would force them to pay the gedo.

These days though the ferd shengo rejects the gedo and traditional council of conflict resolutions are intensively working for the reconciliation especially, of land conflict. To this end the reconciliation process which was formerly concluded with verbal agreement between disputants without any written and signed papers has now changed to producing three copies of written agreement which may be needed for future emerging claims. Of course, the agreement may be important for future litigations in the modern court judicial process as background information. All in all, the government political institutions have been exerting pressure and are inducing some changes on traditional council of conflict resolutions.

\section{Conclusion and recommendations}

In the presence of widespread conflict, the local people in the research site are employing traditional council of conflict resolutions councils. Indeed, members of rural community brought their cases to the traditional mediation forum. Most time, the traditional mediators summoned disputants to resolve their dispute through the elders at the grassroots level, rather than taking it to the modern court. Elders have often engaged in resolving conflicts that arose among farmers. They are shouldering the responsibility as they are vested in the traditional values and authority to do so. Especially, they devoted the weekends and the holydays to this purpose. The traditional mode of conflict resolution is by far convenient to the rural communities of the woreda in handling the problem and establishing sustainable peace between the disputing parties.

However, Despite the fact that traditional council of conflict resolutions have been playing such indispensable role, modern governmental structures namely the ferd-shengo_and some segments of the population consider traditional council of conflict resolutions as frozen and have nothing to do with land problem and ultimately supposed as unacceptable in emerging modern world.

The kebele institutions, which holds the upper hand in the politics of rural Fogera society, denounced traditional council of conflict resolutions, role in the prevailing social revolution. Especially the ferd-shengo, which is acting as, the judicial body of the kebele immensely has worked against traditional council of conflict resolutions.

The cases showed that, land conflicts are initiated even among members of the same family. In addition the traditional land holding system and its simplicity of transferring possession right is fragile, which contributed to the increase in magnitude of land conflicts. It also shows that some individuals who were under aged during the land redistribution are by now grownups and formed their own family. Yet, they are among the landless who were not covered by the 1997 land redistribution. This brings them into conflict with their own family due to their desire to get some plots of land to lead their lives.

Therefore, empowering traditional council of conflict resolutions is very essential and if the government works to ward accommodation by empowering these institutions and against the challenges it faced the traditional council of conflict resolutions would give better function-by-function parallel with modern government institutions. In spite of the current government decentralization effort, there is still lack of good governance among the rural community studied. Thus, the present researcher would like to suggest that empowering traditional council of conflict resolutions enables local community to control and handle their own affairs.

The institutions of the community that are based on traditional rules and norms need to be empowered, so that total livelihood could be mainstreamed in the development effort. Empowerment helps indigenous institutions to rehabilitate them and identify local actors and current conflict dynamics such an approach would ultimately contributes to the alleviation of poverty and achievement of development except empowering their age-old institutions, which can resolve their daily problems at the grass-root level. The good experience with community based indigenous institutions that should be used in anticipation of marginalized rural community side-by -side government political institutions so as to contribute to the development endeavors. This consequently leads rural community to prosperous life by tacking their social, political and economical problems.

\section{Reference}

Befekadu Zeleke and Diribssa Abate. 2005. "Inter state ethnic conflict: Theory and Implication for Ethiopia," in conflict in the Horn: prevention and Resolution, proceedings of the second National workshop of the Ethiopia chapter of OSSREA.

Bloor, G. \& Wood, F. (2006). Key words in qualitative methods: A vocabulary of research concepts. SAGE Publications, London, Thousand Oaks, New Delhi.

\footnotetext{
${ }^{1}$ A money sanctioned against violation of an agreement
} 
Creswell, W. (2009). Research design: qualitative, quantitative, and mixed methods approach (3rd ed.). London: SAGE.

Crystal, D. (2010). Language death. Cambridge: Cambridge University Press.

Given, L. (ed.)(2008). Sage encyclopedia of qualitative research methods. Vol. 1 and 2, Printed in the USA.

Konna, E., 1999. " Customary Conflict Management Mechanism among the Turkana of Kenya: Implication for Conflict Resolution Discourse and Practice," in Africa Principles of Conflict Resolution and Reconciliation. A Paper Presented at the all Africa Conference E.C.A, 8-12 November, Ethiopia: Addis Ababa.

Markakis, J. 1994. "Ethnic Conflict and the state in Ethiopia," in Ethnicity and Conflict in the Horn of Africa Katsuy Fukui and John Markakis, eds._London. James Currey.

Mohiddin, Ahmed. 1999. Resolution and Reconciliation, Rethinking and Reinventing the Traditions. Draft summary and outline. Paper Presented at the All-Africa Conference on African Principles of Conflict Resolution and Reconciliation, 8-12 November 1999, Addis Ababa Ethiopia.

Mwagiru, A. 1999. Conceptualizing Traditional Conflict Managemen Mechanisms. Paper Presented at the AllAfrica Conference on African Principles of Conflict Resolution and Reconciliation, 8-12 November 1999, Addis Ababa Ethiopia.

Nathan, A. 1996. Everything you Need to Know about Conflict Resolutions. New York

Victor, J. ( ed.) (2006). The Sage dictionary of social research methods, London, SAGE Publications Ltd.

Wood, A. 1993. Natural Resource Conflicts in South West Ethiopia: State, Communities, and the Role of The National Conservation Strategy in the Search for Sustainable Development. University of Huddersfied, Nordic Journal of African Studies.

2004. "The Socio-Economic Implication of Land Distribution: A Case Study in Six Rural Communities in North Gondar," in Some Aspects of Rural Land Tenure in Ethiopia: Access, Use and Transfer. Workneh Negatu and Yigremwe Adal (eds.), IDR, A.A.U.

William, Z. ed. 2000. Traditional Cures for Modern Conflicts: African Conflicts "Medicine." Colorado: Lynne Rienner publisher, U.S.A.

Yigremew Adal. 2004. "Land Administration and Management of Communal Land Resources in the post Derg Period: A case study in two Rural Kebelles in North West Ethiopia," in Some Aspects of Rural Land Tenure in Ethiopia: Access, Use and Transfer. Workneh Nigatu and Yigremew Adal (eds) Addis Ababa University: Institute of Development Research Center.

Yohannes, Brihanue. 1998. Conflict and Conflict Resolution among the People of Chihera. MA in Social Anthropology: Addis Ababa University. 